\title{
Dependence between the thickness and the strength of joints of one-layer bitumen sheets
}

\author{
Tomáš Petříček ${ }^{1, *}$, and Petr Kacálek ${ }^{1}$ \\ ${ }^{1}$ Brno University of Technology, Faculty of Civil Engineering, \\ Institute of Building Structures, Veveří 95, 60200 Brno, Czech Republic
}

\begin{abstract}
This paper focuses on the examination of interdependence of thickness of bitumen sheets and strength characteristics of their mechanically fastened joints. Bitumen sheets with two different thicknesses, which are to be used as single-layer mechanically fastened waterproofing membranes, were chosen as samples for experimental measurements. The aforementioned dependence has still not been explicitly documented. The aim of this paper is to confirm or refute the hypothesis that a relationship exists between different thicknesses of bitumen sheets and strength of their joints. The formulation of the results was based on statistical evaluation of laboratory measurement data.
\end{abstract}

\section{Introduction}

The use of a single-layer mechanically anchored system is particularly based on maintaining basic requirements and technological specifications given by the manufacturer [1].

Single-layer systems from bitumen sheets consist of high quality bitumen sheets with the total thickness of at least $5.0 \mathrm{~mm}$. Sometimes, there may be bitumen sheets with the thickness of just $4.00 \mathrm{~mm}$ designed for single-layer systems [2]. However, their application is arguable considering their life span and waterproof safety. Bitumen coating must be of sufficient quality in order to ensure good welding properties and long-term flexibility. The sheets are most commonly reinforced with a coupled filling from PES fleece reinforced with glass fibres.

The critical point of joints is the presence of an anchoring element as a place where force effects caused by wind sucking are caught. Full-area setting of sufficient thickness of joints is a basic requirement to ensure waterproof properties of the system and transfer of force effects caused by wind sucking.

\section{Thickness of single-layer bitumen sheets}

The design of a single-layer bitumen sheet is in compliance with the standard requirements of ČSN P 730606 Waterproofing of buildings - Continuous sheet water proofing - Basic provisions [3], where examples of compositions of continuous sheet water proofing in

\footnotetext{
${ }^{*}$ Corresponding author: petricek.t@ffce.vutbr.cz
} 
relation to hydro physical loading is shown in Annex C. According to this provision, it is possible to use a combined bitumen sheet, $5 \mathrm{~mm}$ thick, in the environment of precipitation water flowing down on continuous sheet surface, or water leaking through protection and operational layers.

To be objective, we need to mention provisions in Annex D of the above mentioned standard ČSN P 730606 [3], which shows factors affecting reliability of continuous sheet waterproofing layers. According to this provision, the reliability of continuous sheet waterproofing consisting of a higher number of perfectly connected layers is higher than that of single-layer continuous sheets, particularly in terms of imperfect joints and risks of layer damage during construction [4], [5].

\section{Experimental measurement}

A pressure chamber was used in which the composition of a roof membrane from a real joint segment of mechanically fastened waterproofing could be subjected to the defined stresses. This wind load test is defined in the Approval Guideline for systems of mechanically fastened waterproofing membranes ETAG 006 [6].

Experimental measurement tests were carried out on a standard tensile testing machine. The specimens were roof membrane segments, not just the waterproofing membrane. Two metal fastening strips in the arms of the upper grip of the machine held the waterproofing membrane in place. These arms transferred the force of the applied stress to the tested material. A pad, to which the waterproofing membrane was fastened by thermal insulation, was clamped into the lower grip. As the lower grip of the tensile testing machine receded, it caused stress to the joint and subsequently its rupture [7].

The test specimens were prepared according to the composition variant S1, i.e. analogically for a roof without thermal insulation with a waterproofing membrane mechanically fastened to an OSB board of $22 \mathrm{~mm}$ thickness. The fastening element to the hard base was a screw with a metal oval washer. The edge of the pressure washer of the fastening element was located $10 \mathrm{~mm}$ from the edge of the lower bitumen sheet. The use of the oval pressure washer was intentional, since it provides better pressure on the lower sheet due to its larger surface area. As a result, the rupture of the test specimens was dependent on the parameters of the bitumen sheet rather than on the failure of the fastening element.

Two bitumen sheet variants were chosen as the waterproofing membranes:

1. Test specimen B - SBS modified bitumen sheet $5.2 \mathrm{~mm}$ thick, carrier: PES $180 \mathrm{~g} / \mathrm{m}^{2}$ reinforced longitudinally with glass fibres, flexibility at low temperatures: $-25^{\circ} \mathrm{C}$, joint length $100 \mathrm{~mm}$

2. Test specimen C - SBS modified bitumen sheet $4.2 \mathrm{~mm}$ thick, carrier: PES $160 \mathrm{~g} / \mathrm{m}^{2}$, reinforced longitudinally with glass fibres, flexibility at low temperatures: $-25^{\circ} \mathrm{C}$, joint length $100 \mathrm{~mm}$ 


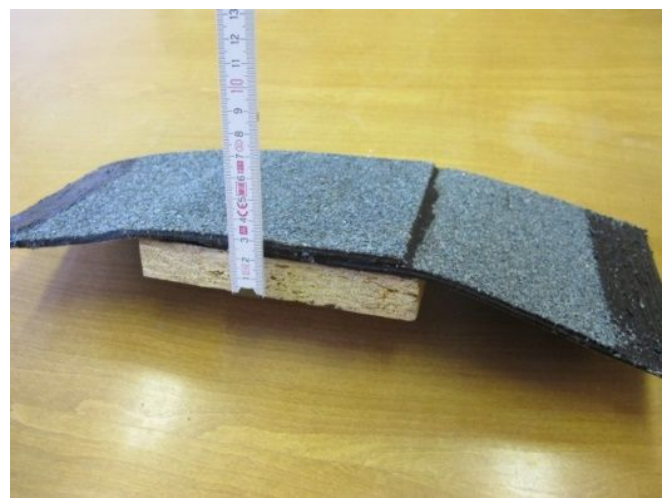

Fig. 1. Test specimen - composition variant $\mathrm{S} 1$. Source: [1].

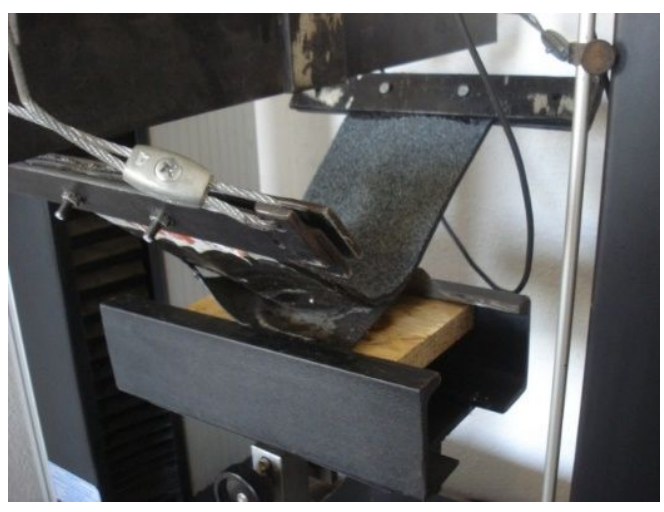

Fig. 2. Test specimen in tensile testing machine during testing. Source: [1].

\section{Evaluation}

Approximately 10 specimens were used for each test sample. The final force is in the form $\bar{x} \pm \bar{\vartheta}(\bar{x})$, where $\bar{x}$ is the arithmetic average and $\bar{\vartheta}(\bar{x})$ is the probable measurement error. The latter was determined on the basis of the error theory for the deviations of the arithmetic average, using the formula:

$$
\bar{\vartheta}(\bar{x})=\frac{2}{3} \sqrt{\frac{1}{n(n-1)} \sum_{i=1}^{n}\left(x_{i}-\bar{x}\right)^{2}} .
$$

\section{Results of experimental measurement and discussion}

When comparing measured values, the final strength of specimen B (thickness $5.2 \mathrm{~m}$ ) is by approx. 19\% higher than of specimen C (thickness $4.2 \mathrm{~mm}$ ). However, the tested specimen $\mathrm{B}$ is reinforced with carrier of higher mass, which may affect the resulting values [8], [9].

Total thickness of the bitumen sheet is also affected by the mass of the filler - higher mass fillers have the higher thickness as well. Therefore, when producing bitumen sheets of a given thickness, bitumen sheets are smaller than when using fillers of lower mass (and smaller thicknesses).

Detailed results and comparison of the results of all specimens are shown in Table 1. 


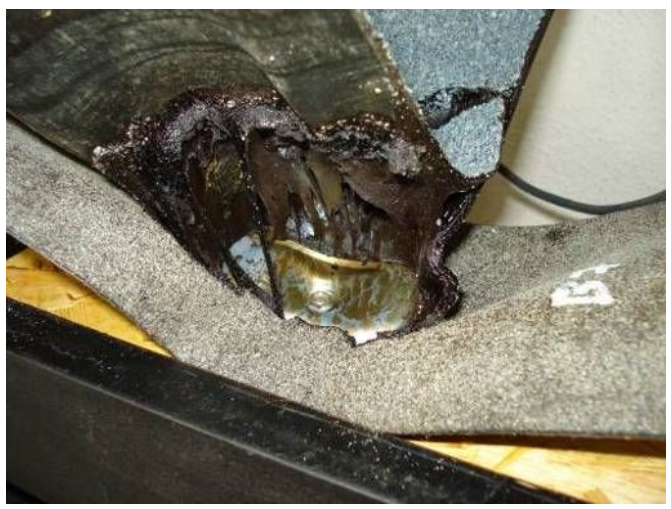

Fig. 3. Typical damage of joint of specimen B. Source: [1].

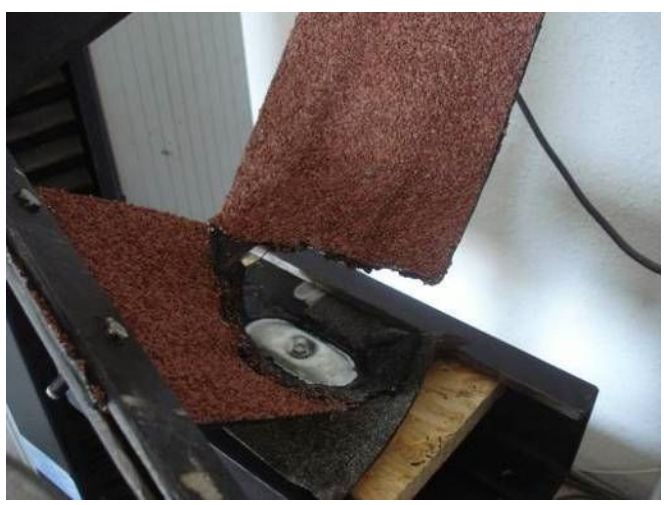

Fig. 4. Opened joint of specimen $\mathrm{C}$ without deformation of anchoring element. Source: [1].

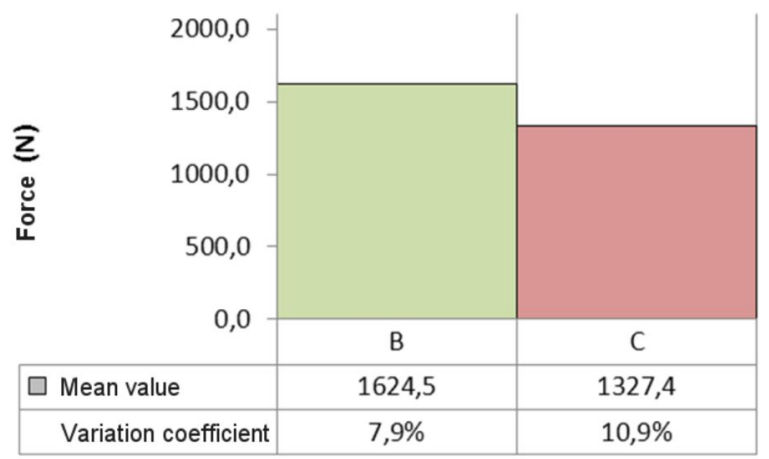

Fig. 5. Comparison of specimen B (sheet of thickness $5.2 \mathrm{~mm}$ ) and specimen $\mathrm{C}$ (sheet of thickness $4.2 \mathrm{~mm}$ ). Source: [1].

Table 1. Comparison of tested specimens

\begin{tabular}{|c|c|c|}
\hline Test specimen: & B & $\mathbf{C}$ \\
\hline Bitumen substance: & \multicolumn{2}{|c|}{ SBS modified } \\
\hline $\begin{array}{l}\text { Flexibility at low } \\
\text { temperatures: }\end{array}$ & \multicolumn{2}{|c|}{$-25^{\circ} \mathrm{C}$} \\
\hline Sheet thickness: & $5.2 \mathrm{~mm}$ & $4.2 \mathrm{~mm}$ \\
\hline Carrier: & $\begin{array}{l}\text { PES } 180 \mathrm{~g} / \mathrm{m}^{2} \text { reinforced } \\
\text { longitudinally with glass fibres }\end{array}$ & $\begin{array}{l}\text { PES } 180 \mathrm{~g} / \mathrm{m}^{2} \text { reinforced } \\
\text { longitudinally with glass fibres }\end{array}$ \\
\hline Overlap width: & \multicolumn{2}{|c|}{$100 \mathrm{~mm}$} \\
\hline $\begin{array}{l}\text { The highest tensile } \\
\text { strength: }\end{array}$ & $\begin{array}{l}\text { longitudinally: } 900( \pm 200) \\
\text { N/50mm, transversally: } \\
700( \pm 150) \mathrm{N} / 50 \mathrm{~mm}\end{array}$ & $\begin{array}{c}\text { longitudinally: } 750( \pm 150) \\
\text { N/50mm, transversally: } 550 \\
( \pm 150) \mathrm{N} / 50 \mathrm{~mm}\end{array}$ \\
\hline Ductility: & $\begin{array}{l}\text { longitudinally and transversally: } \\
\qquad 50( \pm 10) \%\end{array}$ & $\begin{array}{l}\text { longitudinally and transversally: } \\
\qquad 45( \pm 10) \%\end{array}$ \\
\hline
\end{tabular}




\begin{tabular}{|c|c|c|}
\hline Mean value: & $\mathbf{1 6 2 4 . 5} \mathbf{~ N}$ & $\mathbf{1 3 2 7 . 4} \mathbf{~}$ \\
\hline Standard deviation: & $127.6 \mathrm{~N}$ & $144.5 \mathrm{~N}$ \\
\hline Variation coefficient: & $7.9 \%$ & $10.9 \%$ \\
\hline
\end{tabular}

\section{Conclusion}

The experimental results cannot unambiguously determine the degree to which the sheet thickness affects its final strength. In addition, bitumen sheet thickness is related to carrier mass, which significantly affects the final strength.

This paper has been worked out under the project No. LO1408 "AdMaS UP - Advanced Materials, Structures and Technologies", supported by Ministry of Education, Youth and Sports under the „National Sustainability Programme I”.

\section{References}

1. T. Petrríček, Adhesion of joints of mechanically fastened bitumen sheets, Doctoral thesis (Brno: University of Technology, Faculty of Civil Engineering, 2013)

2. ČSN EN 13707+A2. Waterproofing sheets and foils-Reinforced roof waterproofing bitumen sheets - Definitions and characteristics (Prague: The Institute of Technical Standardization, Metrology and State Testing, 12/2009)

3. ČSN P 73 0606. Hydroizolace staveb - Povlakové hydroizolace - Základní ustanovení. (Praha: Úřad pro technickou normalizaci, metrologii, a státní zkušebnictví, 11/2000)

4. J. Plachý, MATEC Web of Conferences, 93, 02004 (2016)

5. J. Plachý, MATEC Web of Conferences, 93, 02006 (2016)

6. ETAG 006. European Technical Approval Guideline - Systems of Mechanically Fastened Flexible Roof Waterproofing Membranes, (Brussels: European Organisation for Technical Assessment - EOTA, 03/2000)

7. R. Smolka, J. Sobotka, J. Šulistová, MATEC Web of Conferences, 93, 01009 (2016)

8. J. Sobotka, R. Smolka, MATEC Web of Conferences, 93, 01008 (2016)

9. P. Kacálek, T. Petř́íček, MATEC Web of Conferences, 93, 03006 (2016) 